\title{
Komposisi hasil tangkapan jaring insang dasar di perairan sekitar Desa Lopana Teluk Amurang
}

\author{
Composition of bottom gill net catches in waters of Lopana Village Amurang Bay \\ AmANDUs BurdaM*, META S. SOMPIE dan LEFRAND MANOPPO \\ Program Studi Pemanfaatan Sumberdaya Perikanan, Fakultas Perikanan dan Ilmu Kelautan, \\ Universitas Sam Ratulangi, Manado 95115
}

\begin{abstract}
Lopana Village is one of the villages in South Minahasa Regency that have relatively wide ocean waters. Local settlements are mostly on the coast, so the activities are focused more on activities related to the utilization of fishery resources. Utilization of the resources is still traditional, such as using vertical hand lines, bottom hand lines, marlin hand line and gill nets. One of the fishing gears used by fishing communities is bottom gill net for demersal fish, even though pelagic fish can also be caught. This study aims to determine the catch composition of bottom gill net which has mesh size 13/4 inches and 2 inches; using a descriptive method that based on a case study. Total catch of both gill nets were 1339 fish. Total catch of 13/4 inches net was 706 fish which consisted of 7 species; and the dominant species were masua (Decapterus russeli, 86.04\%), snappers (Pentapodus bifasciatus, 6.91\%) and kowong (Lutjanus rufolineatus, 3.53\%). The total catch of 2 inches net was 630 fish consisting of 8 species; and the dominant species were masua (88.89\%), tude (Selaroides leptolepis, 3.33\%) and kowong (2.86\%).
\end{abstract}

Keywords: bottom gill net, mesh size, catch composition, Amurang Bay

\begin{abstract}
ABSTRAK
Desa Lopana merupakan salah satu desa yang berada di Kabupaten Minahasa Selatan yang memiliki perairan laut yang relatif luas. Permukiman penduduk sebagian besar berada di pesisir pantai, sehingga kegiatan lebih banyak terfokus pada kegiatan yang berhubungan dengan pemanfaatan sumberdaya perikanan. Pemanfaatan sumberdaya perikanan yang ada masih bersifat tradisional, seperti pancing noru, pancing dasar, pancing ikan tindarung dan jaring insang. Salah satu alat tangkap yang digunakan oleh masyarakat nelayan adalah jaring insang dasar (bottom gillnet) yang digunakan untuk ikan demersal, tetapi dapat juga tertangkap ikan pelagis. Penelitian ini bertujuan untuk mengetahui komposisi hasil tangkapan jaring insang dasar berukuran mata 13/4 inci dan 2 inci; mengikuti metode deskriptif yang didasarkan pada studi kasus. Total hasil tangkapan jaring insang dasar adalah 1339 ekor. Tangkapan jaring insang dasar ukuran mata $13 / 4$ inci sebanyak 706 ekor yang terdiri dari 7 jenis; tetapi yang dominan adalah masua (Decapterus russeli, 86,04\%), gorara (Pentapodus bifasciatus, 6,91\%) dan kowong (Lutjanus rufolineatus, 3,53\%). Tangkapan jaring insang dasar ukuran mata 2 inci sebanyak 630 ekor yang terdiri dari 8 jenis; dan ikan dominan adalah masua (88,89\%), tude (Selaroides leptolepis, 3,33\%) dan kowong $(2,86 \%)$.
\end{abstract}

Kata-kata kunci: Jaring insang dasar, ukuran mata jaring, komposisi tangkapan, Teluk Amurang

\section{PENDAHULUAN}

Desa Lopana merupakan salah satu desa yang berada di Kabupaten Minahasa Selatan yang memiliki perairan laut relatif luas. Permukiman penduduk sebagian besar berada di perairan pantai, sehingga kegiatan lebih banyak terfokus pada kegiatan yang berhubungan dengan pemanfaatan

\footnotetext{
*Penulis untuk penyuratan; email: amandusb@yahoo.com
}

sumberdaya perikanan. Pemanfaatan sumberdaya perikanan yang ada masih bersifat tradisional, seperti pancing (pancing noru, pancing dasar, pancing ikan tindarung) dan jaring (gillnet, pukat cincin). Salah satu alat tangkap yang digunakan oleh masyarakat nelayan adalah jaring insang dasar (bottom gillnet) yang digunakan untuk menangkap ikan pelagis maupun ikan demersal. Sehingga informasi tentang komposisi hasil 